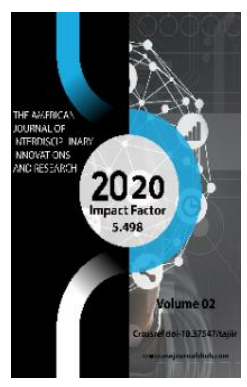

\title{
Genesis Of Geo-Economic Policy Of Uzbekistan
}

\author{
Rustam Rajabboyevich Kobilov \\ Head Of The Samarkand Branch Of The Agency For Public Service Development Under The \\ President Of The Republic Of Uzbekistan
}

Copyright: Original content from this work may be used under the terms of the creative commons attributes 4.0 licence.

\section{ABSTRACT}

In this article, a philosophical analysis of the issues of national geo-economic genesis of Uzbekistan was made. The issue of geo-economic policy was also considered from the point of view of historicity.

\section{KEYWORDS}

Geo-economic policy, Uzbekistan, The Great Silk Road, people, consciousness,Culture, Economy, geo-economic context, genesis, development, history, geographical location.

\section{INTRODUCTION}

The question of the study of the genesis of geoeconomic policy requires that historically and logically it is necessary to find answers to the questions of where, when, from what, how, this phenomenon arose. And without finding an answer to this question, it can not be recognized as a legal derivative of the development of social existence.
The man who first applied the term geoiktisodiot is Edward Lyuttwak, who in the 80-ies of the XX century worked as a consultant in the US Department of state and the National Security Council. He said in his information prepared for these organizations: "geoeconomics is a competition between countries in international competition, in which 
the state provides the maximum advantage for its companies and other economic associations in relation to other companies in the world» [1.8], - indicates the opinion that. After that, a large-scale scientific research work on the study of this issue will begin.

\section{METHODS AND MATERIALS}

Geo-economics ${ }^{1}$ - it is the socio - economic activity carried out with the aim of earning more income, earning a profit by gaining superiority in the competitive field on the basis of integration with the elat, nation, people and states, besides depending on the geographical location, territorial location, production potential, level of entrepreneurship and communication opportunities of a particular elat, nation, nation and states.

This means that geo-economics as a socioeconomic entity is a substrate of geo-economic policy pursued by the nation, people and states $^{2}[2.478]$ will constitute.

The evolution of geo-economic policy carried out by the ancient States located on the territory of Uzbekistan is directly connected with the emergence, formation and development of the "Great Silk Road".

The Great Silk Road has been operating for almost more than 2000 years and has witnessed many historical events in the geoeconomic policy chapter. Therefore, the issue of studying historical events and events that occurred along this path has always attracted the attention of scientists.

\footnotetext{
${ }^{1}$ Geo-economics-this is the Greek deo - "land", the Arabic economy - "Economic, economic issues", which in the Uzbek language means "economic issues there" )

${ }^{2}$ The substrate is derived from the Latin substratum-circle, the basis, which in the
}

The historical position of the Great Silk Road in the formation, formation and development of geo-economic policy carried out by the peoples living in Central Asia is as follows: first, in the II and IV centuries B.C., they connected the Central Asian region with China in the East, and in the West with the Mediterranean Sea and controlled the trade and; third, around the beginning of the IX-XIII century, the system of providing services to caravans, the construction of infrastructures related to trade, the introduction of trade with check in international trade; the further development of this road by the Amir Timur and Timurids in the Fourteenth,fourteenth centuries, trade was promoted by the state, as a result of which the scale of international; from the fifth, in the XVI-XIX centuries, first of all, the great geographical discoveries, and then the mutual disputes between the Khanate and the Emirates, the loss of its leadership position as a result of the conquest of Central Asia by the Russian Empire, the outbreak of various large and small geoeconomic wars, in particular the fact that it became a geo -; it is characterized by the fact that by the end of the twentieth century, the disintegration of the USSR, which was the historical successor of the Russian Empire in its new form and content, was replaced by the emergence of five independent states in Central Asia, as a result of which the road again began to recover, the new one became the.

In Central Asia, the ancient peoplesParthians, Bactrians, Sogdians, khorezmians, Sak - masagats, who lived in the VIII-VII centuries BC, formed the ancient Khorezm,

science of philosophy means something diverse, the general material basis of phenomena and processes, the negation of the generality and similarity between phenomena. 
the ancient Bactrian States and the military alliances of the sak-massaget tribes. As a result of their formation and development, a specific secular order arose here. This order was established on the basis of such principles as mutual trade, economic and military assistance to each other, the peaceful settlement of disputes, the consolidation of the mutual Union on the basis of marriages, which are blood ties.

In Central Asia, the Middle Ages evolutionary development of geo-economic policy in the world of kalaversa is directly related to the domestic and foreign policy of the Amir Temur and Temurids state.

Our great-grandfather, Amir Temur, conquered the 27 countries of the world at that time [3.69] with great intensity, he created geo-political principles that were inherent in the search and development of the life of the peoples who lived on these lands.

We would not exaggerate if we say that Amir Temur's very rational, just entrepreneurial policy is a rational cornerstone of the modern geo-economic policy of our independent country.

In Central Asia, trade, economic, cultural and spiritual ties did not stop despite the fact that there were small disagreements during the khanates in the XVII - XIX centuries.

Summarizing the above views on the origin, formation and development of geo-economic policy in the socio-economic life of the peoples of Central Asia, one can draw the following conclusions.

1. The difficult natural conditions in Central Asia have led people to live as a community by interacting with each other. And their favorable geographical location laid the ground for establishing trade, economic, cultural and spiritual ties, which led to the passage of large and small roads from there.

Free economic trade is defined by the peculiarity of Technopolis in which cities are characterized, more precisely, by the fact that each city specializes in the production of any individual individual goods or several groups of goods. For example, Samarkand was famous for its paper, Bukhara tattoo lace, Chust dappies, shahrichon knives, Margilan silk and silk products.

\section{RESULTS}

As a result of the liquidation of independent states in Central Asia by the Russian Empire, especially the Russian Bolsheviks, the geoeconomic policy that existed here from time immemorial was also undermined. The territory of Central Asia was transformed into the "octoberyat", "Komsomol", "Communist", so-called "free slaves", loyal to the material raw material base of the former USSR, and to the ideas of MarxismLeninism from the birth of its peoples.

After a long struggle in 1991, when the Uzbek people gained their true, worldrecognized independence, a new modern period of geo-economic policy began in its historical development.

The independent state of Uzbekistan, within the framework of its geo-economic landscape of today's world, will have to formulate and develop its national geo-economic landscape, first of all, in order to solve its strategically important tasks for the purpose of conducting geo-economic policy, that is, to earn income and profit. In general, the geo-economic landscape of today's world is not created by itself, but is formed, formed and developed as a result of the efforts of the national economy to find a specific place in the World Economic Space. In carrying out this, the issue of the full 
use of the opportunities of the national economy on the ground of allocating the existing World Economic spaces to a moving small-scale economic space, depending on what kind of hierarchical stage the historical development of the elat, nation, people and states stands for is taken as a methodological basis.

Over the past 30 years, the system of individual ownership, which remained from the former USSR, has been liquidated, and instead of it, an unprecedented work has been carried out on the formation, formation and development of a market economy based on multi-ownership. More precisely, a new class of property owners, who became owners of private property, appeared. A new generation of small businesses and private entrepreneurs began to operate economically on the basis of innovative methods.

Therefore, our President Sh.M.Mirziyoyev: "when an active entrepreneur says, We understand business people who are able to produce competitive products,most importantly,create new jobs, feed not only himself and his family,but also bring profit to the whole society. If necessary, we should give them every opportunity to gain experience and mutually beneficial cooperation in leading companies and organizations abroad " [5.87], he said.

\section{CONCLUSION}

This is not the end of the work on the formation and development of the National geo-economic landscape of Uzbekistan. In fact, this work is among the social philosophical issues that await its solution. It should be emphasized that our experience in the practical implementation of this issue can serve as a template for the formation of the National geo-economic landscape of other countries.

\section{REFERENCES}

1. Jean K., Savona P. (1997). Geoeconomics (domination of economic space) TRANS. from Italian-M., P. 207.

2. Dictionary of foreign words. (1985). Moscow: Rus. yaz., P. 608.

3. Timur regulations. (1996). G. Gulum Publishing house of literature and art named after, P. 344.

4. Address of the president of the Republic of Uzbekistan Shavkat Mirziyoyev to the Oliy Majlis. The consent of our people is the highest assessment given to our activities. (2018). 3-volume. Tashkent: "Uzbekistan", P. 508.

5. Omonov, Q., \& Karimov, N. (2020). Importance Of Ancestoral Heritage. The American Journal of Social Science and Education Innovations, 2(09), 196-202.

6. Karimov, N. R. (2020). A True Successor of Great Central Asian Scholars. Journal «Bulletin Social-Economic and Humanitarian Research,(7), 62-69.

7. Boltabayevich, B. B., \& Shodievna, B. O. (2020). Individual Approach To The Formation Of Artistic And Creative Talents Of Students In Art Schools. The American Journal of Social Science and Education Innovations, 2(08), 637-642. 